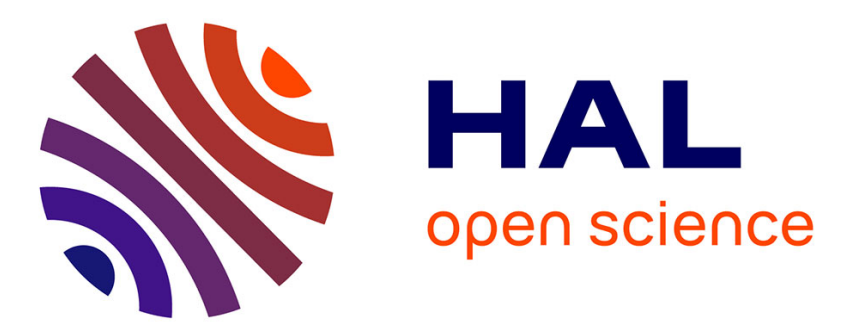

\title{
Mahorones, Highly Brominated Cyclopentenones from the Red Alga Asparagopsis taxiformis
}

Stephane Greff, Mayalen Zubia, Grégory Genta-Jouve, Lionel Massi, Thierry Perez, Olivier P. Thomas

\section{- To cite this version:}

Stephane Greff, Mayalen Zubia, Grégory Genta-Jouve, Lionel Massi, Thierry Perez, et al.. Mahorones, Highly Brominated Cyclopentenones from the Red Alga Asparagopsis taxiformis. Journal of Natural Products, 2014. hal-01760562

\section{HAL Id: hal-01760562 \\ https://hal-amu.archives-ouvertes.fr/hal-01760562}

Submitted on 6 Apr 2018

HAL is a multi-disciplinary open access archive for the deposit and dissemination of scientific research documents, whether they are published or not. The documents may come from teaching and research institutions in France or abroad, or from public or private research centers.
L'archive ouverte pluridisciplinaire HAL, est destinée au dépôt et à la diffusion de documents scientifiques de niveau recherche, publiés ou non, émanant des établissements d'enseignement et de recherche français ou étrangers, des laboratoires publics ou privés. 
This document is confidential and is proprietary to the American Chemical Society and its authors. Do not copy or disclose without written permission. If you have received this item in error, notify the sender and delete all copies.

\section{Mahorones, highly brominated cyclopentenones from the red alga Asparagopsis taxiformis}

\begin{tabular}{|r|l|}
\hline Journal: & Journal of Natural Products \\
\hline Manuscript ID: & np-2013-01094h.R3 \\
\hline Manuscript Type: & Full Paper \\
\hline Date Submitted by the Author: & 09-Apr-2014 \\
\hline Complete List of Authors: & $\begin{array}{l}\text { GREFF, stephane; Aix-Marseille Universite, DFME IMBE UMR 7263 } \\
\text { Zubia, Mayalen; UMR EIO, } \\
\text { Genta-Jouve, Gregory; UMR 8638 CNRS, } \\
\text { Massi, Lionel; 2Institut de chimie de Nice (ICN), } \\
\text { Perez, Thierry; IMBE - AMU, } \\
\text { Thomas, Olivier; University of Nice-Sophia Antipolis, Chemistry }\end{array}$ \\
\hline
\end{tabular}

SCHOLARONE ${ }^{\mathrm{m}}$

Manuscripts 


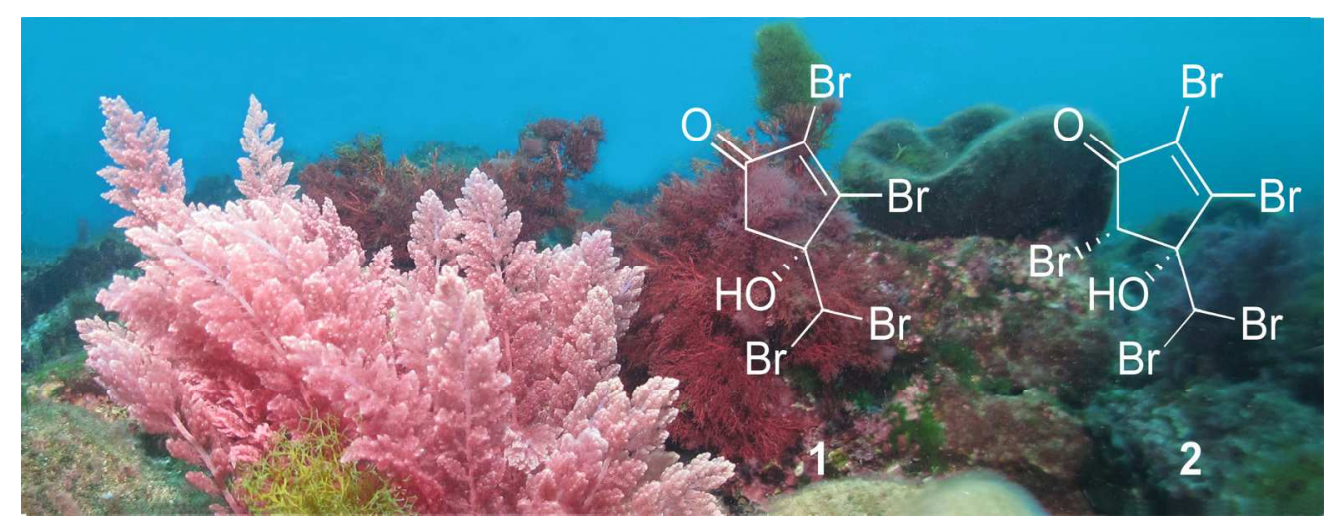

$708 \times 271 \mathrm{~mm}(72 \times 72$ DPI $)$

1

2

3

4

5

6
7

8

9

10

11

12

13

15

16

17

18

19

20

2

22

23

24

25

26

27

28

29

30

31

32

33

34

35

36

37

38

39

40

41

42

43

44

45

46

47

48

49

50

51

52

53

54

55

56

57

58

59

60 


\section{Mahorones, Highly Brominated Cyclopentenones}

\section{from the Red Alga Asparagopsis taxiformis}

Stéphane Greff, ${ }^{\dagger}$ Mayalen Zubia, ${ }^{\ddagger}$ Grégory Genta-Jouve, ${ }^{\S}$ Lionel Massi, ${ }^{\perp}$ Thierry Perez,,$^{\dagger}$ Olivier P. Thomas ${ }^{1 *}$

† Institut Méditerranéen de Biodiversité et d'Ecologie marine et continentale, IMBE UMR 7263

CNRS / IRD / Aix-Marseille Université / Université d'Avignon et des Pays du Vaucluse, Station Marine d'Endoume, rue de la Batterie des Lions, 13007 Marseille, France.

$\ddagger$ Agence pour la Recherche et la Valorisation Marine, ARVAM, 97490 Sainte-Clotilde, La Réunion, France.

§ Laboratoire de Pharmacognosie, UMR 8638 CNRS, Université Paris Descartes, Sorbonne Paris Cité, Faculté des Sciences Pharmaceutiques et Biologiques, 4 avenue de l'Observatoire, 75006 Paris, France

$\perp$ Nice Institute of Chemistry-PCRE, UMR 7272 CNRS, Université de Nice Sophia-Antipolis, Faculté des Sciences, Parc Valrose 06108, Nice, France. 
The presence of non-indigenous species in marine ecosystems has strongly increased during the last decades due to globalisation of trade exchanges and transports. ${ }^{1-3}$ In this context, seaweeds have attracted much attention, ${ }^{4-9}$ because of the negative impacts they can have on the environment counterbalanced by the benefits they may provide to human societies. ${ }^{10-11}$ While a general consensus has arisen on the need to minimise these impacts and to limit them in the future, little is known about the ecological and chemical processes which trigger the proliferation of an introduced species and the impact that chemical cues may have on native species. ${ }^{12}$ Widely distributed from tropical to temperate waters, species of the genus Asparagopsis (Rhodophyta, Bonnemaisoniaceae) are spreading worldwide, affecting several marine ecosystems. ${ }^{5,13}$ The genus is composed of cryptogenic populations, and it contains only two species to date: $A$. armata Harvey and A. taxiformis (Delile) Trevisan de Saint-Léon. From a chemical perspective, these algae are particularly interesting due the production of a high diversity of halogenated metabolites. ${ }^{14}$ Thoroughly studied in the 1970 s, A. taxiformis produces low molecular weight halogenated compounds with one to four linear carbons, including methanes, ethenes, acetic acids, acetamides, propanols, propanones, propenes, acrylic acids, propylene oxide, propyl and propenyl acetates, butenols and butenones, ${ }^{15-21}$ which exhibit an array of biological activities (Supporting Information). ${ }^{22}$

To better understand the mechanisms associated with the possible proliferation of these algae, we initiated a chemical ecological study that explores the role of secondary metabolites in their interaction with native species. In the present part of the study our objectives were: i) to isolate and characterize the secondary metabolites produced by this alga; ii) to assess the ecotoxicological activities of fractions and pure compounds from this alga; iii) and to evaluate their potential as therapeutic agents due to the large biomass of algae available. Unexpectedly, the phytochemical study of specimens of A. taxiformis collected in the Indian Ocean led to the 
isolation of two new highly brominated cyclopentenones, named mahorone (1) and 5bromomahorone (2). We report herein the isolation, the structure elucidation, and also the ecotoxicological as well as antiinfective and antitumor activities of these compounds.

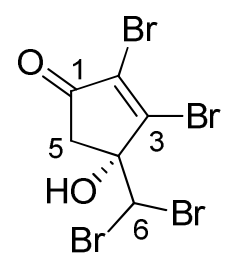

mahorone (1)

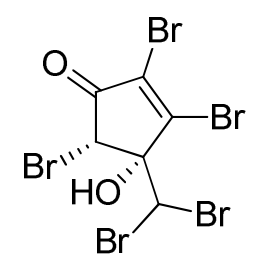

5-bromomahorone (2)

\section{RESULTS AND DISCUSSION}

Specimens of A. taxiformis were collected off the coast of Mayotte (Indian Ocean). Samples were kept frozen, freeze-dried and ground before extraction by $\mathrm{MeOH} / \mathrm{CH}_{2} \mathrm{Cl}_{2}(1: 1)$ and sonication. The resulting extract was then fractioned by reversed-phase $\left(\mathrm{C}_{18}\right)$ vacuum liquid chromatography using solvents of decreasing polarities $\left(\mathrm{H}_{2} \mathrm{O}, \mathrm{MeOH}, \mathrm{CH}_{2} \mathrm{Cl}_{2}\right)$. The chemical profile of the methanolic fraction showed a very promising UHPLC-DAD-ELSD profile, evidencing major compounds with UV profiles unknown for this alga. A succession of HPLC purification steps on this fraction resulted in the isolation of both new compounds $\mathbf{1}$ and $\mathbf{2}$.

The isotopic pattern in the (-)-HRESIMS spectrum of $\mathbf{1}$ was indicative of a pentabromoderivative with the most intense peak at $m / z$ 506.6090, which was in accordance with a molecular formula $\mathrm{C}_{6} \mathrm{H}_{5} \mathrm{Br}_{5} \mathrm{O}_{2}$ if associated with the most common [M-H] $]^{-}$ion observed in (-)-ESIMS. The very low $\mathrm{H} / \mathrm{C}$ ratio and the presence of a large number of heteroatoms made the structure elucidation highly challenging by NMR. Indeed, the ${ }^{1} \mathrm{H}$ NMR spectrum of $\mathbf{1}$, first performed in $\mathrm{CD}_{3} \mathrm{OD}$, indicated three signals for a total integration of three, two of them corresponding to an $\mathrm{AB}$ system at $\delta_{\mathrm{H}} 3.33(\mathrm{~d}, J=18.5 \mathrm{~Hz}, 1 \mathrm{H}, \mathrm{H}-5 \mathrm{a})$ and $2.77(\mathrm{~d}, J=18.5 \mathrm{~Hz}, 1 \mathrm{H}, \mathrm{H}-5 \mathrm{~b})$ and a singlet at $\delta_{\mathrm{H}} 6.06(1 \mathrm{H}, \mathrm{H}-6)$ (Table 1). The ${ }^{13} \mathrm{C}$ NMR and HSQC spectra confirmed the presence 
of six carbons corresponding to the following signals: $\delta_{\mathrm{C}} 194.9(\mathrm{C}, \mathrm{C}-1)$ assigned to a ketone function; $\delta_{\mathrm{C}} 131.8(\mathrm{C}, \mathrm{C}-2)$ and $161.2(\mathrm{C}, \mathrm{C}-3)$ assigned to a tetrasubstituted double bond; one saturated methylene, one saturated methine, and one deshielded and saturated quaternary carbon. The lack of vicinal and longer range proton-proton coupling information led us to rely on HMBC correlations to assess the structure of $\mathbf{1}$ (Figure 1). The proton signals corresponding to the C-5 AB methylene system were HMBC correlated to the other five carbons of the molecule while the proton signal of the C-6 methine was only correlated to C-3, C-4, and C-5. These data suggested that the $\mathrm{C}-5$ methylene, the $\mathrm{C}-1$ ketone and the $\mathrm{C}-2 / \mathrm{C}-3$ unsaturation were placed within a cyclic system while the C-6 methine was expected to be exocyclic. In this case, the C-6 methine should be substituted on the resulting five-membered ring. An acyclic system would not lead to H-6/C-3 coupling while, in the case of a six-membered ring system, H-5 and C-3 would be ${ }^{4} J$ coupled and would not exhibit an intense HMBC correlation as observed. Additionally, H-6 would be expected to couple to four carbons and, in our case, only three couplings are observed. Among the several possibilities still existing for the arrangement around this ring, the $\mathrm{H}-5 \mathrm{a} / \mathrm{C}-6$ and $\mathrm{H}-$ 5b/C-6 together with the H-6/C-5 HMBC correlations were only consistent with a substitution of the C-6 methine at the C-4 quaternary carbon, one of the positions $\alpha$ to the C-5 methylene. Finally, the H-6/C-3 HMBC correlation allowed us to rule out a last possibility for the endocyclic $\alpha, \beta$-unsaturated ketone, and the ketone was unambiguously placed at $\mathrm{C}$ - 1 , the second position $\alpha$ to the C-5 methylene. Among the five bromine atoms identified by HRMS, two of them were placed on the C-2/C-3 tetrasubstituted double bond, which was in agreement with the detected chemical shifts of the corresponding ${ }^{13} \mathrm{C}$ atoms. ${ }^{23}$ 
Table 1. ${ }^{1} \mathrm{H}(500 \mathrm{MHz})$ and ${ }^{13} \mathrm{C}(125 \mathrm{MHz}) \mathrm{NMR}$ Data for $\mathbf{1}$ and $\mathbf{2}$ in $\mathrm{CD}_{3} \mathrm{OD}$.

\begin{tabular}{|c|c|c|c|c|c|}
\hline \multirow[b]{2}{*}{ position } & \multicolumn{3}{|c|}{ mahorone (1) } & \multicolumn{2}{|c|}{ 5-bromomahorone (2) } \\
\hline & $\delta_{\mathrm{C}}$, mult. & $\delta_{\mathrm{H}}$, mult. $(J$ in Hz $)$ & $\operatorname{HMBC}(\mathrm{H} \rightarrow \mathrm{C})$ & $\delta_{\mathrm{C}}$, mult. & $\delta_{\mathrm{H}}$, mult. \\
\hline 1 & 194.9, C & & & 192.1, C & \\
\hline 2 & $131.8, \mathrm{C}$ & & & $130.4, \mathrm{C}$ & \\
\hline 3 & 161.2, C & & & $159.9, \mathrm{C}$ & \\
\hline 4 & $84.0, \mathrm{C}$ & & & $82.8, \mathrm{CH}$ & \\
\hline $\begin{array}{l}5 \mathrm{a} \\
5 \mathrm{~b}\end{array}$ & $46.3, \mathrm{CH}_{2}$ & $\begin{array}{l}3.33, \mathrm{~d}(18.5) \\
2.77, \mathrm{~d}(18.5)\end{array}$ & $1,2,3,4,6$ & $50.9, \mathrm{CH}$ & $5.29, \mathrm{~s}$ \\
\hline 6 & $50.7, \mathrm{CH}$ & $6.06, \mathrm{~s}$ & $3,4,5$ & $49.3, \mathrm{CH}$ & $6.20, \mathrm{~s}$ \\
\hline
\end{tabular}

a.

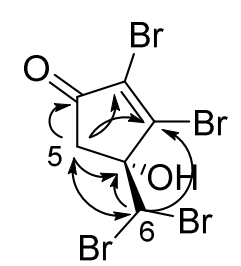

1 b.<smiles></smiles>

2

Figure 1. a. Key HMBC $(\mathrm{H} \rightarrow \mathrm{C})$ correlations for 1; b. key NOESY (double headed arrow) correlation for 2 .

In order to determine whether the resulting bromines and alcohol were placed on the C-4 quaternary carbon or the C-6 methine, we first relied on a possible metabolic pathway leading to these compounds (Scheme 1). Indeed, chemical shifts modeling would not lead to any definitive conclusion on the position of the substituents at C-4 and C-6 due to close electronic effects of these substituents. 
<smiles>C=CC(Br)C(Br)C(=O)C(Br)Br</smiles>

Scheme 1. Biogenetic hypothesis for mahorone (1).

The six carbons of $\mathbf{1}$ suggested that the construction of the skeleton could originate from the condensation of two brominated acetones, as these derivatives have already been reported from this alga. ${ }^{15,18,24}$ The enol reactivity of the ketone would be involved, first through the connection of the second ketone partner by nucleophilic substitution, and secondly through the cyclization by an aldol-type reaction. Consequently, this hypothesis allowed us to propose the presence of the alcohol at C-4 and two bromines at C-6. In order to ascertain the position of the substituents on the cycle, we performed ${ }^{13} \mathrm{C}$ NMR modeling for the three possible isomers $\mathrm{a}, \mathrm{b}$ and $\mathrm{c}$ (Table 2). Data obtained for $\mathbf{1}$ fit best with theoretical values of a, even more when considering values obtained for a compound already reported in the literature with bromines at C-2 and C-3. ${ }^{23}$ 
Table 2. Comparison between Experimental and Theoretical ${ }^{13} \mathrm{C}$ NMR Chemical Shifts for isomers $\mathbf{a}, \mathbf{b}$ and $\mathbf{c}$ of $\mathbf{1}$.

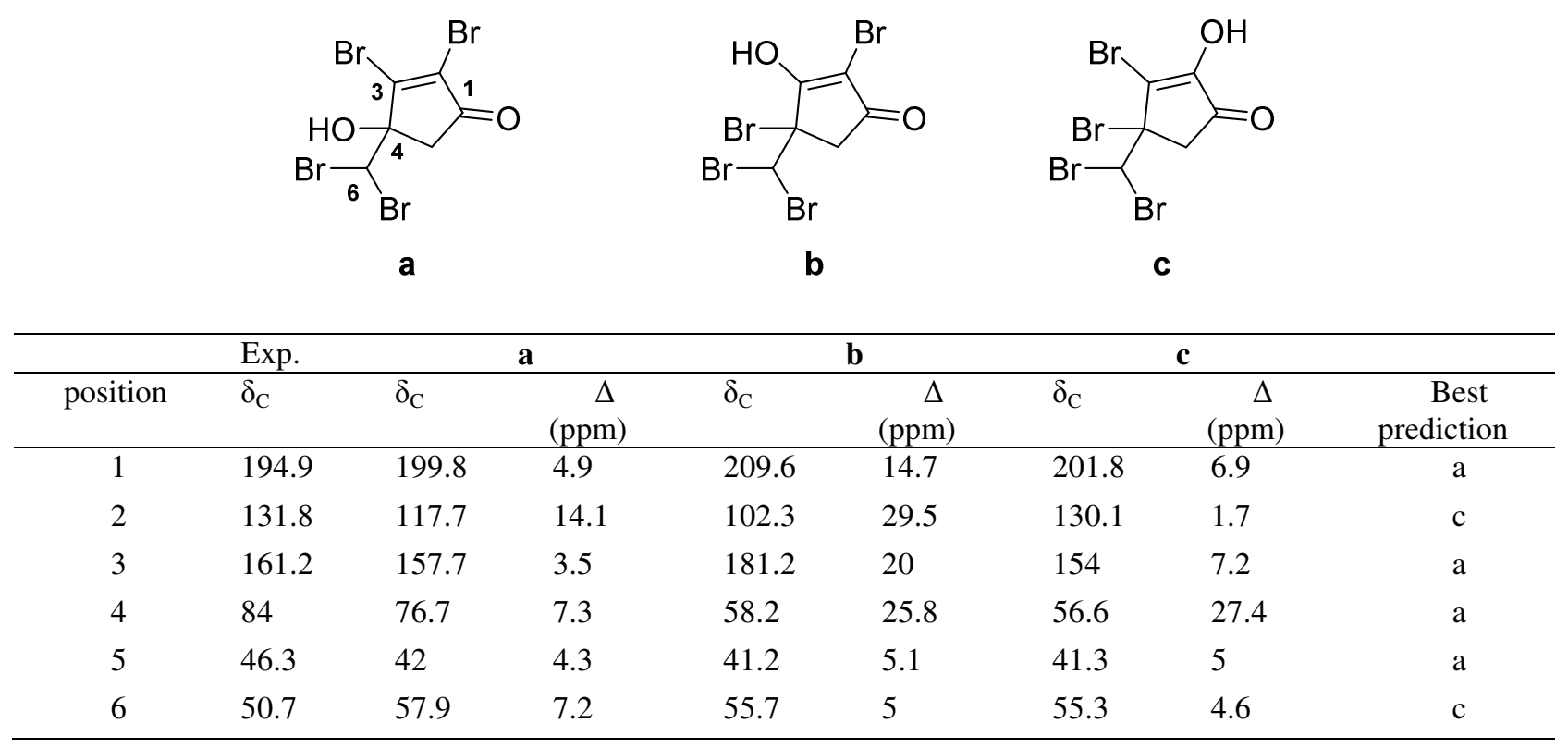

The fifth bromine atom of the molecular formula obtained by (-)-HRESIMS was consequently suspected to be an additional bromide ion obtained through an ion-molecule reaction during ionization leading to $[\mathrm{M}+\mathrm{Br}]^{-}$and then a molecular formula of $\mathrm{C}_{6} \mathrm{H}_{4} \mathrm{Br}_{4} \mathrm{O}_{2}$ for 1 . The EIMS spectrum of $\mathbf{1}$ was fully consistent with this assumption. The ion cluster with four bromine atoms was observed at $m / z$ 428 (1:4:6:4:1) which are odd values and that should then correspond to the molecular peak. The base peak at $m / z 255\left(1: 2: 1,\left[\mathrm{M}-\mathrm{CHBr}_{2}\right]\right)$ confirmed the five-membered ring and the exocyclic $-\mathrm{CHBr}_{2}$ substituent. Bromide adducts are not frequent in (-)-ESIMS and they have usually been observed when halide salts are added to the solvents used. ${ }^{25-26}$ In our case the bromide may be present in the methanolic solution just like for sodium adducts or by exchange with another molecule during the ionization process. This reactivity may originate from the absence of acidic protons in the mahorones but also because of the high polarisability of the numerous bromine atoms of the molecules. ${ }^{27}$ In order to test this hypothesis, we decided to add salts to our samples to induce the formation of ion adducts. Positive ions were not observed by 
(+)-ESIMS (adding $\mathrm{LiCl}$ or $\mathrm{NH}_{4} \mathrm{Cl}$ ) but when adding $\mathrm{NH}_{4} \mathrm{Cl}$ we observed an isotopic ion at $\mathrm{m} / z$ 459 in the (-)-ESIMS spectrum. The presence of this chloride adduct then confirms our assumption (Supporting Information).

Due to the low level of flexibility for mahorone (1), we anticipated that the use of electronic circular dichroism could easily lead to the determination of the absolute configuration. Even if the helicity rule proposed by Snatzke is well adapted for $s$-trans $\alpha, \beta$-unsaturated ketones, ${ }^{28}$ some recent computational studies applied to 4-substituted 2-cyclohexenones demonstrated that molecular modeling was necessary to determine the absolute configuration in these cases. ${ }^{29} \mathrm{We}$ consequently decided to first perform a conformational analysis of $\mathbf{1}$ in order to assess the theoretical ECD spectrum of each calculated conformer (Supporting Information). While the conclusion was not clear for the $\pi_{\mathrm{C}=\mathrm{C}}-\pi^{*} \mathrm{C}=\mathrm{O}$ transition at $288 \mathrm{~nm}$, all of the calculated conformers obtained for the $S$ configuration show a positive Cotton effect at $372 \mathrm{~nm}$ for the less intense $\mathrm{n}_{\mathrm{C}=\mathrm{O}^{-}}$ $\pi^{*} \mathrm{C}=\mathrm{O}$ electronic transition. The experimental data showing a negative Cotton effect for this transition were consistent with an $R$ configuration for the asymmetric carbon at C-4.

The molecular formula of 2 was deduced as $\mathrm{C}_{6} \mathrm{H}_{3} \mathrm{Br}_{5} \mathrm{O}_{2}$ on the basis of the (-)-HRESIMS spectrum exhibiting an isotopic cluster centered at $\mathrm{m} / \mathrm{z} 586.5183$ assuming the same bromide adduct seen for $\mathbf{1}$. In the ${ }^{1} \mathrm{H} \mathrm{NMR}$ spectrum of $\mathbf{2}$ performed in $\mathrm{CD}_{3} \mathrm{OD}$, only two singlets were observed at $\delta_{\mathrm{H}} 5.29(\mathrm{H}-5)$ and $6.20(\mathrm{H}-6)$. Due to the additional bromine of the molecular formula and the disappearance of one proton from the methylene group of $\mathbf{1}$, we suspected the substitution of one proton of the methylene at C-5 by a fifth bromine atom. Support was given by EIMS through the isotopic cluster centered at $m / z$. $506(1: 5: 10: 10: 5: 1 ; 5 \mathrm{Br})$ and a base peak at $m / z 333\left(1: 3: 3: 1 ;\left[\mathrm{M}-\mathrm{CHBr}_{2}\right]\right)$. The relative configuration around the five-membered ring was assessed using NOESY. Indeed, a clear nOe was observed between H-6 and H-5 which is consistent with a most likely cis-configuration between the hydroxy at C-4 and the bromine at C- 
5 (Figure 1). Because the ECD spectrum of 2 presented the same Cotton effects as those encountered for $\mathbf{1}$, the $4 R, 5 S$ absolute configuration was assigned for this compound.

Ecotoxicological activities of chromatographic fractions and pure compounds $\mathbf{1}$ and $\mathbf{2}$ were evaluated against a marine bioluminescent bacteria (Vibrio fischeri) using a standardized Microtox assay in order to target bioactive metabolites and hypothesize their role in the environment. Bioactivity was quantified by measuring the direct effect on the metabolism of the bacteria indicated by a decrease in light emitted after 15 min exposure. Toxicity was expressed as: i) $\mathrm{EC}_{50}$, that represents the concentration (in $\mu \mathrm{g} \cdot \mathrm{mL}^{-1}$ ) of compounds/extracts that reduces bacteria light to a half the initial light; and ii) as gamma units relative to one $\mathrm{mg}$ dry mass.mL $\mathrm{m}^{-1}$ as this index appears to be relevant for ecological comparisons. ${ }^{30}$ Interestingly, the $\mathrm{MeOH}$ fraction containing 1 and 2 displays the lowest $\mathrm{EC}_{50}\left(2.8 \mu \mathrm{g} \cdot \mathrm{mL}^{-1}\right)$ and the maximum gamma (6.452) (Table 3). According to Martì et al., who set the threshold between toxic and non-toxic samples at 0.5 gamma units, this fraction appears as the most bioactive. As a reference, the extract of Falkenbergia rufolanosa, the tetrasporophytic stage of A. armata, presented a gamma value of 5.204, and was consequently considered as highly toxic. ${ }^{30}$ Pure compounds were also evaluated following the same methodology and revealed high toxicities with $\mathrm{EC}_{50}$ values of 0.07 $\mu \mathrm{g} . \mathrm{mL}^{-1}(0.16 \mu \mathrm{M})$ and $0.08 \mu \mathrm{g} \cdot \mathrm{mL}^{-1}(0.16 \mu \mathrm{M})$ for $\mathbf{1}$ and $\mathbf{2}$, respectively. ${ }^{31}$ 
Table 3. $\mathrm{EC}_{50}\left(\mu \mathrm{g} \cdot \mathrm{mL}^{-1}\right)$ and Gamma Units of Fractions of Asparagopsis taxiformis Gametophyte Stage (Microtox Bioassay after 15 min Exposure). EC 50 values are means \pm SD (n $=3)$.

\begin{tabular}{lllll}
\hline & & \multicolumn{2}{c}{$\begin{array}{c}\mathrm{EC}_{50} \\
\left(\mu \mathrm{g} \cdot \mathrm{mL}^{-1}\right)\end{array}$} & Gamma \\
\hline Fraction & Solvent fractionating & Mean & $\mathrm{SD}$ & \\
\hline $\mathrm{A} 1$ & $\mathrm{H}_{2} \mathrm{O}$ & $<1000$ & 0.0 & 0.000 \\
$\mathrm{~A} 2$ & $\mathrm{H}_{2} \mathrm{O} / \mathrm{MeOH}(1: 1)$ & 6.0 & 0.6 & 0.135 \\
$\mathrm{~A} 3$ & $\mathrm{MeOH}$ & 2.8 & 0.3 & $\mathbf{6 . 4 5 2}$ \\
$\mathrm{A} 4$ & $\mathrm{MeOH} / \mathrm{CH}_{2} \mathrm{Cl}_{2}(1: 1)$ & 11.6 & 1.4 & 0.012 \\
$\mathrm{~A} 5$ & $\mathrm{CH}_{2} \mathrm{Cl}_{2}$ & 10.2 & 0.9 & 0.000 \\
\hline $\mathrm{B} 1$ & $\mathrm{Hexane}_{\mathrm{B} 2}$ & 2.9 & 0.2 & 0.028 \\
$\mathrm{~B} 3$ & EtOAne/EtOAc $(1: 1)$ & 5.8 & 0.9 & 0.081 \\
$\mathrm{~B} 4$ & EtOAc/MeOH & 48.0 & 3.4 & 0.001 \\
B5 & $\mathrm{MeOH}$ & 170.5 & 1.6 & 0.003 \\
\hline
\end{tabular}

Several studies already reported the antimicrobial/antifungal activities of $A$. taxiformis extracts from medium to low polarity fractions, evidencing a large range of biological activities. ${ }^{32-37}$ However, biological assays using single compounds from the genus remain scarce. ${ }^{22,38-39}$ The release of brominated metabolites involved in the control of epiphytic bacterial communities has been reported from A. armata and Bonnemaisonia asparagoides. ${ }^{39-40}$ Antibacterial and quorum sensing inhibition activities of $\mathrm{MeOH}$ extracts of $A$. taxiformis have also been demonstrated. ${ }^{41}$ The high toxicities exhibited by the methanolic fraction and compounds $\mathbf{1}$ and $\mathbf{2}$ of $A$. taxiformis against a bacterial marine pathogen may be considered as a real advantage for the species. Although their release in the environment has not been demonstrated, we might anticipate their potential role in the interaction of this species with other micro- and/or macro-organisms.

At the same time, we decided to assess the pharmaceutical potential of these compounds, keeping in mind a possible biotechnological use of this widespread macroalga. Isolated metabolites $\mathbf{1}$ and $\mathbf{2}$ were thus tested against human bacterial and fungal pathogens: Gram negative bacteria (Acinetobacter baumannii, two strains of Escherichia coli 2884 and 5746, 
Pseudomonas aeruginosa), Gram positive bacteria (Staphylococcus aureus MRSA/MSSA methicillin resistant/sensitive strains) and fungi (Aspergillus fumigatus and Candida albicans). Mahorones 1 and 2 exhibited the strongest effect against A. baumannii (MIC80 of 8 and 16 $\mu \mathrm{g} . \mathrm{mL}^{-1}$ respectively) (Table 4). Compound 1 exhibited a weak effect on E. coli 5746, while both compounds inhibited the cell growth of Gram positive S. aureus MRSA in the same range.

Table 4. Antibacterial and Antifungal $\mathrm{MIC}_{80}$ values of $\mathbf{1}$ and $\mathbf{2}$.

\begin{tabular}{|c|c|c|c|c|c|}
\hline & & & 1 & 2 & Control \\
\hline & & & \multicolumn{3}{|c|}{$\mathrm{MIC}_{80}\left(\mu \mathrm{g} \cdot \mathrm{mL}^{-1}\right)$} \\
\hline \multirow{4}{*}{$\begin{array}{l}\text { Gram-negative } \\
\text { bacteria }\end{array}$} & A. baumannii & & 8 & 16 & Rifampicin 1 \\
\hline & E. coli $(2884)$ & & $>32$ & $>32$ & Novobiocin 0.3 \\
\hline & E. $\operatorname{coli}(5746)$ & & 16 & 32 & Novobiocin 0.1 \\
\hline & P. aeruginosa & & $>10$ & $>10$ & Ciprofloxacin 1.5 \\
\hline \multirow{2}{*}{$\begin{array}{l}\text { Gram-positive } \\
\text { bacteria }\end{array}$} & S. aureus MRSA & & 16 & 16 & Imipenem 8 \\
\hline & S. aureus MSSA & & $>32$ & $>32$ & Penicillin 0.01 \\
\hline \multirow{3}{*}{$\begin{array}{l}\text { Filamentous } \\
\text { fungi }\end{array}$} & A. fumigatus & & $>32$ & $>32$ & \\
\hline & $\begin{array}{l}\text { A. fumigatus } \\
\text { caspofungin enhancer }\end{array}$ & + & $>32$ & $>32$ & \\
\hline & caspofungin enhancer & & $>32$ & $>32$ & \\
\hline Yeast & C. albicans & & $>32$ & $>32$ & \\
\hline
\end{tabular}

Cytotoxicities of both compounds were also evaluated on an immortalized hepatocyte (Fa2N4) and several human tumor cell lines including lung (A549), liver (HepG2), colon (HT29) and breast (MCF7). Neither compound showed any inhibition of tumor cells, while compound $\mathbf{1}$ evidenced a cytotoxic effect on healthy liver cells ( $53 \%$ inhibition of cell growth at $5 \mu \mathrm{M}$ ). No other study has reported cytotoxic activities of A. taxiformis compounds. In addition, Genovese et al. did not find any effect when studying the toxicity of extracts of A. taxiformis on digestive glands of mussels, Mytilus galloprovincialis, ${ }^{36}$ while Zubia et al. highlighted significant cytotoxicities of $\mathrm{MeOH} / \mathrm{CH}_{2} \mathrm{Cl}_{2}$ extracts of $A$. armata against two tumor cell lines. ${ }^{42}$ 


\section{EXPERIMENTAL SECTION}

General Experimental Procedures. Optical rotations were determined using a Perkin Elmer 343 polarimeter. UV and ECD spectra were measured at $20{ }^{\circ} \mathrm{C}$ on a $\mathrm{J}-810$ spectropolarimeter (Jasco), and the IR spectrum was measured on a Bruker Tensor 27 spectrometer. ${ }^{1} \mathrm{H}$ and ${ }^{13} \mathrm{C}$ NMR spectra were recorded on a Bruker Avance $500 \mathrm{MHz}$ spectrometer; chemical shifts were referenced to residual solvent signals $\left(\mathrm{CD}_{3} \mathrm{OD}, \delta_{\mathrm{H}}=3.31, \delta_{\mathrm{C}}=49.0\right)$. EIMS spectra were recorded on an Agilent 6890 gas chromatograph coupled to a mass spectrometer $5973 \mathrm{~N}$ at $70 \mathrm{eV}$. HRESIMS was performed on a LTQ Orbitrap mass spectrometer (Thermo Finnigan) in negative mode. UHPLC data were acquired on a Dionex Ultimate 3000 equipped with Ultimate 3000 RS pump, 3000 Diode Array Detector and Agilent Technologies 380-ELSD. HPLC purifications of the fractions were achieved on a Jasco LC-2000 system equipped with a PU-2087 Plus preparative pumping system and a UV-2075 Plus detector.

Collection and Identification of the Alga. Asparagopsis taxiformis gametophyte stages were sampled off the coast of Mayotte (Airport, $12.8213^{\circ} \mathrm{S}, 45.2901^{\circ} \mathrm{E}$ ) in April 2011. Our chemical investigations were focused on the gametophyte stage of the algal life cycle because it represents the highest biomass in native ecosystems and this stage interacts frequently with autochthonous species such as corals and native macrophytes. Voucher specimens were deposited at the MARS Herbarium (MARS07731/Saint-Charles center at Aix-Marseille University). Fresh material was conveyed in ice to the laboratory, frozen at $-20{ }^{\circ} \mathrm{C}$ and freeze-dried before grinding. Ground material was protected from moisture by adding silica gel packed into paper bags, and stored at $70{ }^{\circ} \mathrm{C}$ before extractions.

Extraction and Isolation. Dry material (185 g) was extracted three times with $500 \mathrm{~mL}$ $\mathrm{MeOH} / \mathrm{CH}_{2} \mathrm{Cl}_{2}$ (1:1) and sonication (5 min). After filtration, the solutions were pooled and concentrated to dryness at $40{ }^{\circ} \mathrm{C}$ to give $17.7 \mathrm{~g}$ of a brown residue. The extract was first 
solubilized in $\mathrm{CH}_{3} \mathrm{CN}$ and then in $\mathrm{CH}_{2} \mathrm{Cl}_{2}$ to give fractions $\mathrm{A}$ and $\mathrm{B}(3.7 \mathrm{~g}$ and $1.9 \mathrm{~g}$, respectively). Fraction A was subjected to reversed-phase vacuum liquid chromatography (VLC, non end-capped $\mathrm{C}_{18}$ Polygoprep 60-50, Macherey-Nagel) eluting with $\mathrm{H}_{2} \mathrm{O}, \mathrm{H}_{2} \mathrm{O} / \mathrm{MeOH}(1: 1)$, $\mathrm{MeOH}, \mathrm{MeOH} / \mathrm{CH}_{2} \mathrm{Cl}_{2}(1: 1)$ and $\mathrm{CH}_{2} \mathrm{Cl}_{2}$, giving fractions $\mathrm{A} 1$ to A5. Fraction $\mathrm{B}$ was subjected to normal phase VLC (diol, LiChroprep DIOL 40-63 $\mu \mathrm{m}$, Macherey-Nagel) eluting with hexane, hexane/EtOAc (1:1), EtOAc, EtOAc/MeOH (1:1) and $\mathrm{MeOH}$, giving fractions B1 to B5. Chemical analyses of A1-A5, B3-B5 were performed by UHPLC-DAD-ELSD. The purification was performed on a preparative XSELECT CSH Phenylhexyl column (19 mm x $250 \mathrm{~mm}, 5 \mu \mathrm{m}$, Waters). Elution rate was set at $12 \mathrm{~mL} \cdot \mathrm{min}^{-1}$. Initial conditions, maintained during 5 min, were followed by a linear gradient of $\mathrm{CH}_{3} \mathrm{CN}$ in $\mathrm{H}_{2} \mathrm{O}$ (35 to $90 \%$ for $\mathrm{A} 3$ ) over 22 min. The first purification afforded pure compound $1(14.3 \mathrm{mg})$. Compound 2 was further purified on a semipreparative column Synergi Fusion-RP 80A (10 mm x $250 \mathrm{~mm}, 4 \mu \mathrm{m}$, Phenomenex). Elution was performed at $5 \mathrm{~mL} \cdot \mathrm{min}^{-1}$ in isocratic mode at 55:45 $\left(\mathrm{CH}_{3} \mathrm{CN} / \mathrm{H}_{2} \mathrm{O}\right)$, and this second purification afforded pure compound $2(0.8 \mathrm{mg})$.

Mahorone (1): yellow amorphous solid; $[\alpha]_{\mathrm{D}}^{20}+3(c 0.45, \mathrm{MeOH}) ; \mathrm{UV}(\mathrm{MeOH}) \lambda_{\max }(\log \varepsilon)$

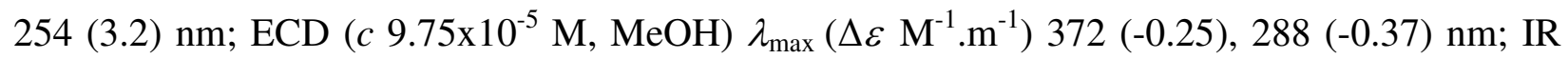
(neat) $v_{\max } 3200\left(\right.$ br), 1728, 1582, 1212, 1045, 1022, 1000, $735 \mathrm{~cm}^{-1} ;{ }^{1} \mathrm{H}$ and ${ }^{13} \mathrm{C}$ NMR data see Table 1; EIMS (70 eV) m/z (\%) $428\left[\mathrm{M}^{+},{ }^{79} \mathrm{Br}_{2}{ }^{81} \mathrm{Br}_{2}\right](<1), 349$ (4), 347 (4), 258 (3), 257 (50), 256 (6), 255 (100), 253 (53), 229 (6), 227 (13), 225 (7), 199 (4), 197 (3), 173 (3), 161 (3), 159 (3), 133 (8), 131 (10), 119 (4), 117 (5), 51 (4), 50 (3), 42 (3); (-)-HRESIMS m/z 506.6090 $[\mathrm{M}+\mathrm{Br}]^{-}$(calcd for $\left.\mathrm{C}_{6} \mathrm{H}_{4} \mathrm{Br}_{5} \mathrm{O}_{2}, 506.6092, \Delta-0.2 \mathrm{ppm}\right)$.

5-Bromomahorone (2): yellow amorphous solid; $[\alpha]_{\mathrm{D}}{ }^{20}+2(c 0.27, \mathrm{MeOH})$; UV (MeOH) $\lambda_{\max }$ $(\log \varepsilon) 254(3.2) \mathrm{nm} ; \mathrm{ECD}\left(c 5.64 \times 10^{-5} \mathrm{M}, \mathrm{MeOH}\right) \lambda_{\max }\left(\Delta \varepsilon \mathrm{M}^{-1} \cdot \mathrm{m}^{-1}\right) 370(-0.59), 288(-0.70)$ $\mathrm{nm} ;{ }^{1} \mathrm{H}$ and ${ }^{13} \mathrm{C}$ NMR data see Table 1; EIMS (70 eV) $\mathrm{m} / z(\%) 506\left[\mathrm{M}^{+},{ }^{79} \mathrm{Br}_{3}{ }^{81} \mathrm{Br}_{2}\right](<1), 337$ 
(32), 335 (95), 334 (11), 333 (100), 332 (16), 331 (35), 330 (14), 268 (14), 266 (13), 255 (17), 253 (15), 251 (14), 225 (19), 223 (19), 197 (11), 187 (9), 185 (9), 175 (10), 173 (14), 133 (19), 131 (24), 79 (11), 62 (11), 61 (10), 50 (10); (-)-HRESIMS m/z 586.5183 [M+Br] $]^{-}$(calcd for $\left.\mathrm{C}_{6} \mathrm{H}_{3} \mathrm{Br}_{6} \mathrm{O}_{2}, 586.5177, \Delta+1.02 \mathrm{ppm}\right)$.

Ecotoxicological Assays. Microtox (Microbics) is a standardized ecotoxicological bioassay that measures the toxic effect of compounds/extracts on bioluminescent marine bacteria, Vibrio fischeri (NRRL B-11177 strain). ${ }^{43}$ Tests were carried out to evaluate the toxicity of A1 to B5 fractions, as well as those of pure compounds $\mathbf{1}$ and $\mathbf{2}$. Fractions were made up to an initial concentration of 1000 or $2000 \mu \mathrm{g} \cdot \mathrm{mL}^{-1}$ (500 $\mu \mathrm{g} \cdot \mathrm{mL}^{-1}$ for pure compounds) using artificial seawater containing $2 \%$ acetone to assist compound dissolution. Concentrations tested were 45 , $22.5,11.25$ and $5.625 \%$ of the initial concentrations after $15 \mathrm{~min}$ of bacteria exposure to toxins. Samples were diluted when necessary to fit apparatus recommendations. Toxicities, given as conventional gammas from Microtox, are measured as $\left(I_{0} / I_{t}\right)-1$ where $I_{0}$ and $I_{t}$ are the intensity of the bioluminescences before and after exposure time, respectively. A linear relationship is obtained when plotting the log of gamma against the log of the tested concentrations, and permit the direct determination of an $\mathrm{EC}_{50}$ value (equivalent to a gamma of 1) representing the concentration of fractions (or compounds) that reduces the initial bioluminescence to $50 \%$. However, because extract concentrations (and consecutive $\mathrm{EC}_{50}$ ) are expressed as $\mu \mathrm{g}$ of extracts.mL $\mathrm{m}^{-1}$ of solution independent of extraction yields, comparisons between samples/species were difficult. So, new regression curves were generated replacing original concentrations $(\mu \mathrm{g}$ extracts.mL $\mathrm{m}^{-1}$ ) by modified ones (mg DM alga. $\mathrm{mL}^{-1}$ of solution) as described:

Concentrations $\left(\mathrm{mg} \mathrm{DM}\right.$ alga.mL $\left.\mathrm{m}^{-1}\right)=$ concentration of extract $\left(\mu \mathrm{g} \cdot \mathrm{mL}^{-1}\right)$. dry mass of initial sample $(\mathrm{mg}) /$ dry mass of fraction $(\mu \mathrm{g})$. 
Using modified concentrations, mathematical relationships were generated using Statgraphics (four concentrations in triplicate, except for fraction B5 because of insufficient material), and unconventional gamma units relative to one $\mathrm{mg}$ of alga. $\mathrm{mL}^{-1}$ of solution were calculated, according to the formula.

Gamma $=10^{\mathrm{B}}$ where $\mathrm{B}$ is the intercept of generated regressions for each fraction (Supporting Information).

Antimicrobial Assays. All bioassays were performed by Fundacion Medina (Granada Spain). Antimicrobial assays were carried out against six bacteria (Acinetobacter baumannii, Escherichia coli, Pseudomonas aeruginosa as Gram negative bacterial models; Staphylococcus aureus MSSA, Staphylococcus aureus MRSAas examples of Gram-positive bacteria). Positive controls were used against Gram-negative strains (rifampicin, novobiocin, ciprofloxacin for $A$. baumanii, E. coli, P. aeruginosa respectively) and Gram positive strains (imipenem, penicillin and tunicamycin for S. aureus MSSA, S. aureus MRSA respectively). Amphotericin B was used as negative controls against all strains. The liquid assay procedure was employed to measure microbial susceptibility of all strains. Antifungal assays were performed on Candida albicans as a yeast model and Aspergillus fumigatus as a filamentous fungus, using the liquid assay procedure.

In the liquid assay procedure, compounds were tested in a liquid growth medium dispensed in 96 or 384 well plates (Costar 3370 and 3680 from Corning) inoculated with a bacterial or fungal suspension. Following overnight incubation at $37^{\circ} \mathrm{C}$, the plates were examined for visible bacterial/fungal growth as evidenced by turbidity or fluorescence. Compounds were dissolved in DMSO to a stock solution of $1 \mathrm{mM}$, and tested at the final concentration of $5 \mu \mathrm{M}$ in triplicate in the same experiment. For A. baumannii, P. aeruginosa, E. coli and S. aureus liquid assays, $90 \mu \mathrm{L}$ of the appropriate diluted inoculums are mixed with $8.4 \mu \mathrm{L}$ of medium (Luria Broth) and $1.6 \mu \mathrm{L}$ 
of a $0.312 \mathrm{mM}$ (DMSO 100\%) stock solution of compounds per well. The A. fumigatus and $C$. albicans liquid assays were performed in 384-well microtiter plates: $0.5 \mu \mathrm{L}$ per well of the compounds from a $0.5 \mathrm{mM}$ solution followed by the inoculum to a final volume of $50 \mu \mathrm{L}$. The medium used was a modified RPMI medium: 10.4 g.L - $^{-1}$ of RPMI-1640 medium (R8755 from Sigma), 6.7 g.L.-1 of Yeast Nitrogen Base (YNB) (BD - Becton, Dickinson and Company), $1.8 \%$ (w/v) glucose and $40 \mathrm{mM}$ HEPES ( $\mathrm{pH} 7.1)$. An amphotericin B curve $\left(0.5\right.$ to $\left.4 \mu \mathrm{g} \cdot \mathrm{mL}^{-1}\right)$ was used as a control. Cellular viability was scored using resazurin at the final concentration of 0.002 $\% .^{45}$

Cytotoxicity Assays. Five human cancer cell lines (A549, HepG2, HT29, MCF7, MiaPAca2) and healthy liver cells (Fa2N4) were used to evaluate cytotoxic effects according to the MTT methodology. ${ }^{46}$ Cells were seeded at a concentration of $3 \times 10^{4}$ cells/well in $200 \mu \mathrm{L}$ culture medium and incubated at $37{ }^{\circ} \mathrm{C}$ at $5 \% \mathrm{CO}_{2}$. Compounds $\mathbf{1}$ and $\mathbf{2}$ were prepared at $1 \mathrm{mM}$ in $100 \%$ DMSO. One $\mu \mathrm{L}$ of this solution was added to $199 \mu \mathrm{L}$ of culture medium (1/200 dilution), and left in contact with the cells for $24 \mathrm{~h}$ at $37^{\circ} \mathrm{C}$ in a $5 \% \mathrm{CO}_{2}$ incubator. After this time, a MTT solution was prepared at $5 \mathrm{mg} \cdot \mathrm{mL}^{-1}$ in PBS $1 \mathrm{X}$ and then diluted at $0.5 \mathrm{mg} \cdot \mathrm{mL}^{-1}$ in MEM without phenol red. $100 \mu \mathrm{L}$ of the MTT solution was added to each well. The plates were gently shaken and incubated for $3 \mathrm{~h}$ at $37^{\circ} \mathrm{C}$ in $5 \% \mathrm{CO}_{2}$ incubator. The supernatant was removed and $100 \mu \mathrm{L}$ of DMSO $100 \%$ was added. The plates were gently shaken to solubilize the formed formazan. The absorbance was measured using a multireader Victor at a wavelength of $570 \mathrm{~nm}$. Methyl methanesulfonate MMS ( $8 \mathrm{mM}$ ) was used as positive control, and DMSO $1 \%$ as a negative control (same concentration as compounds).

\section{Calculations.}


NMR prediction was achieved using the PERCH software (PERCH Solutions Ltd). After importation of the molecular model, geometry optimisation was conducted using Monte Carlo analysis. The most stable conformer was used to obtain the calculated chemical shifts.

ECD calculations were performed at $298 \mathrm{~K}$ using the Gaussian03 program package. ${ }^{47}$ The Density Functional Theory (DFT) was used to scan the potential energy surface at the B3LYP/6$311 \mathrm{G}^{*}$ level to identify the most stable conformers. TDDFT was employed to calculate excitation energy (in $\mathrm{eV})$ and rotatory strength $\mathrm{R}$ in dipole velocity $\left(R_{\text {vel }}\right)$ and dipole length $\left(R_{\text {len }}\right)$ forms. The calculated rotatory strengths were simulated in ECD curve by using the software package SpecDis. $^{48}$

Statistical Analyses. Statgraphics Centurion 15.2.11.0 was used to determine linear regressions.

Supporting Information Available. All NMR spectra, HRESIMS, EIMS and ECD spectra for $\mathbf{1}$ and 2. This material is available free of charge via the Internet at http://pubs.acs.org.

\section{Corresponding Author \\ * E-mail: olivier.thomas@ unice.fr, Tel: +33(0)49207-6134, Fax: +33(0)49207-6189.}

\section{Present Addresses}

† Ecosystème Insulaires Océaniens, UMR 241 IFREMER/IRD/ILM, Université de la Polynésie Française, BP 6570, 98702 Faa'a, Tahiti

\section{Author Contributions}

The manuscript was written through contributions of all authors. All authors have given approval to the final version of the manuscript.

\section{Notes}


The authors declare no competing financial interest.

\section{ACKNOWLEDGMENT}

This work was supported by the ERA-NET Biome project "SEAPROLIF". M. Gaysinski (PFTC Nice) and J.-M. Guigonis (Plateforme Bernard Rossi) are acknowledged for performing the NMR and HRMS spectra respectively. The ECD spectra were obtained with the help of D. Bonhomme. 


\section{REFERENCES}

(1) Ruiz, G. M.; Carlton, J. T.; Grosholz, E. D.; Hines, A. H. Am. Zool. 1997, 37, 621-632.

(2) Streftaris, N.; Zenetos, A.; Papathanassiou, E., Globalisation in marine ecosystems : The story of non-indigenous marine species across European seas. CRC Press: Boca Raton, FL, USA, 2005; Vol. 43, p 35.

(3) Molnar, J. L.; Gamboa, R. L.; Revenga, C.; Spalding, M. D. Front. Ecol. Environ. 2008, $6,485-492$.

(4) Valentine, J. P.; Magierowski, R., H.; Johnson, C. R. Bot. Marina 2007, 50, 351.

(5) Boudouresque, C. F.; Verlaque, M. Mar. Pollut. Bull. 2002, 44.

(6) Pickering, T. D.; Skelton, P.; Sulu, R. J. Bot. Marina 2007, 50, 338.

(7) Meinesz, A. Bot. Marina 2007, 50, 373-384.

(8) Johnson, C. R.; Chapman, A. R. O. Bot. Marina 2007, 50, 321-325.

(9) Hewitt, C. L.; Campbell, M. L.; Schaffelke, B. Bot. Marina 2007, 50, 326.

(10) Boudouresque, C. F. Les espèces introduites et invasives en milieu marin; GIS Posidonie Publisher: Marseilles, France, 2008.

(11) Schaffelke, B.; Hewitt, C. L. Bot. Marina 2007, 50, 397.

(12) Shine, C.; Williams, N.; Gündling, L., A Guide to Designing Legal and Institutional Frameworks on Alien Invasive Species. In Environmental Policy and Law Paper No. 40, Union, I.-T. W. C., Ed. 2000.

(13) Andreakis, N.; Kooistra, W. H. C. F.; Procaccini, G. Mol. Ecol. 2009, 18, 212-226.

(14) Kladi, M.; Vagias, C.; Roussis, V. Phytochem. Rev. 2004, 3, 337-366.

(15) Fenical, W. Tetrahedron Lett. 1974, 15, 4463-4466.

(16) Burreson, B. J.; Moore, R. E.; Roller, P. Tetrahedron Lett. 1975, 473-476.

(17) Woolard, F. X.; Moore, R. E.; Roller, P. P. Tetrahedron 1976, 32, 2843-2846. 
(18) McConnell, O.; Fenical, W. Phytochemistry 1977, 16, 367-374.

(19) Woolard, F. X.; Moore, R. E.; Roller, P. P. Phytochemistry 1979, 18, 617-620.

(20) Abrahamsson, K.; Ekdahl, A.; Collen, J.; Pedersen, M. Limnol. Oceanogr. 1995, 40, 1321-1326.

(21) Sugano, M.; Sato, A.; Nagaki, H.; Yoshioka, S.; Shiraki, T.; Horikoshi, H. Tetrahedron Lett. 1990, 31, 7015-7016.

(22) McConnell, O. J.; Fenical, W. Antimicrobial agents from marine red algae of the family Bonnemaisoniaceae. In Marine Algae in Pharmaceutical Sciences, Hoppe, H. A., Levring, T., Tanaka, Y., Ed. Water de Gruyter: Berlin, New York, 1979; pp 403-427.

(23) Vadalà, A.; Finzi, Paola V.; Zanoni, G.; Vidari, G. Eur. J. Org. Chem. 2003, 642-648.

(24) Burreson, B. J.; Moore, R. E.; Roller, P. P. J. Agric. Food Chem. 1976, 24, 856-861.

(25) Kumar, M. R.; Prabhakar, S.; Kumar, M. K.; Reddy, T. J.; Vairamani, M. Rapid Commun. Mass Spectrom. 2004, 18, 1109-1115.

(26) Cai, Y.; Cole, R. B. Anal. Chem. 2002, 74, 985-991.

(27) Zhai, H.; Zhang, X. Water Res. 2009, 43, 2093-2100.

(28) Snatzke, G. Angew. Chem., Int. Ed. Engl. 1979, 18, 363-377.

(29) Kwit, M.; Gawronski, J.; Boyd, D. R.; Sharma, N. D.; Kaik, M. Org. Biomol. Chem. 2010, 8, 5635-5645.

(30) Marti, R.; Uriz, M. J.; Turon, X. Mar. Ecol. Prog. Ser. 2004, 282, 73-85.

(31) Botsford, J. L. ATLA-Altern. Lab. Anim. 2002, 30, 539-550.

(32) Bouhlal, R.; Riadi, H.; Martínez, J.; Bourgougnon, N. Afr. J. Biotechnol. 2010, 9, 63656372.

(33) Genovese, G.; Leitner, S.; Minicante, S. A.; Lass-Florl, C. Mycoses 2013, 56, 516-519. 
(34) Manilal, A.; Sujith, S.; Kiran, G. S.; Selvin, J.; Shakir, C.; Gandhimathi, R.; Lipton, A. P. Ann. Microbiol. 2009, 59, 207-219.

(35) Gonzalez del Val, A.; Platas, G.; Basilio, A.; Cabello, A.; Gorrochategui, J.; Suay, I.; Vicente, F.; Portillo, E.; Jimenez del Rio, M.; Reina, G. G.; Pelaez, F. Int. Microbiol. 2001, 4, $35-40$.

(36) Genovese, G.; Faggio, C.; Gugliandolo, C.; Torre, A.; Spano, A.; Morabito, M.; Maugeri, T. L. Mar. Environ. Res. 2012, 73, 1-6.

(37) Genovese, G.; Tedone, L.; Hamann, M. T.; Morabito, M. Mar. Drugs 2009, 7, 361-366.

(38) Fenical, W.; McConnell, O. J.; Stone, A. In Antibiotics and antiseptic compounds from the family Bonnemaisoniaceae (Florideophyceae), Proceedings of the Ninth International Seaweed Symposium, Santa Barbara - California, 20-27 August 1977, 1979; Jensen, A.; Stein, J. R., Eds. Science Press, Princeton: Santa Barbara - California, 1979; pp 387-400.

(39) Paul, N. A.; de Nys, R.; Steinberg, P. D. Mar. Ecol. Prog. Ser. 2006, 306, 87-101.

(40) Nylund, G. M.; Persson, F.; Lindegarth, M.; Cervin, G.; Hermansson, M.; Pavia, H. FEMS Microbiol. Ecol. 2010, 71, 84-93.

(41) Jha, B.; Kavita, K.; Westphal, J.; Hartmann, A.; Schmitt-Kopplin, P. Mar. Drugs 2013, $11,253-265$.

(42) Zubia, M.; Fabre, M.-S.; Kerjean, V.; Deslandes, E. Bot. Marina 2009, 52, 268-277.

(43) Johnson, B. T. Microtox ${ }^{\circledR}$ Acute Toxicity Test. In Small-scale Freshwater Toxicity Investigations, Blaise, C.; Férard, J.-F., Eds. Springer Netherlands: 2005; pp 69-105.

(44) Barry, A. L. Procedure for Testing Antimicrobial Agents in Agar Media: Theoretical Considerations. In Antibiotics in Laboratory Medicine, Lorian, V., Ed. Williams \& Wilkins: Baltimore, Maryland, 1986; pp 1-26. 
(45) Suay, I.; Arenal, F.; Asensio, F.; Basilio, A.; Angeles Cabello, M.; Teresa Díez, M.;

García, J.; González del Val, A.; Gorrochategui, J.; Hernández, P.; Peláez, F.; Francisca Vicente, M. Antonie Van Leeuwenhoek 2000, 78, 129-140.

(46) Supino, R. MTT Assays. In In Vitro Toxicity Testing Protocols, O'Hare, S.; Atterwill, C. K., Eds. Humana Press: Hatfield UK, 1995; Vol. 43, pp 137-149.

(47) Gaussian, Inc.: Wallingford, CT, USA 2003.

(48) Bruhn, T.; Schaumlöffel, A.; Hemberger, Y.; Bringmann, G. Chirality 2013, 25, $243-$ 249. 
Table of Contents

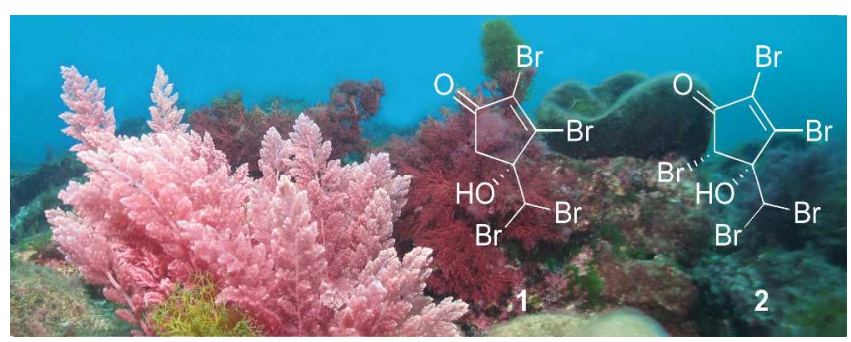

